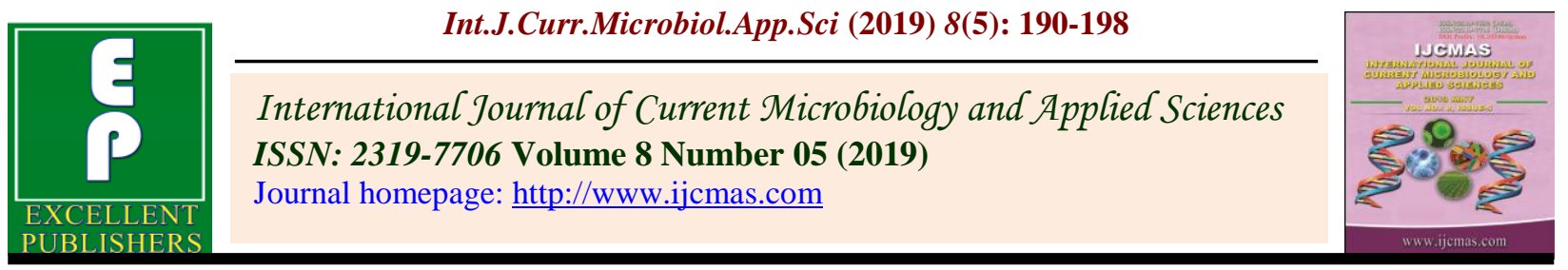

Original Research Article

https://doi.org/10.20546/ijcmas.2019.805.023

\title{
In vitro Antagonistic Activity of Fungal and Bacterialbio Control Agents against Chilli Fruit Rot Incited by Colletotrichum capsici
}

\author{
N. Kavi Bharathi ${ }^{1}$, N. Revathy $^{1 *}$, E.G. Ebenezar ${ }^{1}$ and R.P. Gnanamalar $^{2}$ \\ ${ }^{1}$ Department of Plant Pathology, ${ }^{2}$ Department of Plant Breeding and Genetics, Agricultural \\ College and Research Institute, Madurai, India \\ *Corresponding author
}

A B S T R A C T

\begin{tabular}{|l|}
\hline Ke y w or d s \\
Chilli, \\
$\begin{array}{l}\text { Colletotrichum } \\
\text { capsici, Biocontrol, } \\
\text { Dual plate }\end{array}$ \\
\hline Article Info \\
\hline $\begin{array}{l}\text { Accepted: } \\
\text { 04 April } 2019 \\
\text { Available Online: } \\
\text { 10 May } 2019\end{array}$ \\
\hline \hline
\end{tabular}

\section{Introduction}

Chilli is considered as one of the most important commercial spice crops and as it is so widely used it has been given the name wonder spice. Chilli (Capsium annuum) belonging to the family Solanaceae is the most commonly cultivated and an indispensable source of vegetable and spice across the tropical and subtropical regions of the world. India is the second largest producer, consumer and exporter of chilli. Chillies are used for various purposes, both green and ripe chilli fruits contains an alkaloid capsaicin, which are used to impart pungency into the various food preparations, it is used in pharmaceutical industries, cosmetics, preparation of oleoresin and other industrial resources (Bosland and Votava, 2003). Chilli is susceptible to many foliar and soil borne fungal diseases among the biotic stress, fruit rot caused by Colletotrichum capsici is one of the most destructive disease which causes heavy yield loss in almost all chilli growing areas. The symptoms of the disease were noticed on leaves, flowers and 
fruits. The disease incited as dark spot, watersoaked lesions that rapidly expand. In some cases, the lesions are brown, and then turn black due to the formation of setae and sclerotia (Roberts, 2001). Bio control is an effective alternate that provide disease control, while being relatively harmless to humans, selective in mode of action, difficult for pathogens to develop resistance (Singh et al., 2005).In the present study shows the role of fungal and bacterial biocontrol agents against Colletotrichum capsici under in vitro which will effective in the field level.

\section{Materials and Methods}

Colletotrichum capsici isolate was collected from fruit rot infected chilli plants in Chellampatti village of Madurai, Tamil Nadu by tissue segment method (Rangaswami and Mahadevan, 1999).

The isolate was confirmedby morphological appearance and by ITCC (Accession no: 10025.19). A single pure culture was prepared from the isolate and maintained in PDA slants used for further experiments.

\section{Isolation of bacterial and yeast antagonists from phylloplane region of chilli plants}

Healthy and fruit rot infected chilli fruit samples, at ripening stage, were collected from different chilli growing areas of Tamil Nadu. For isolation of antagonist, two grams of each sample were surface sterilized and blot dried.

Cut pieces of samples $(5 \mathrm{~mm})$ were taken into $250 \mathrm{ml}$ Erlenmeyer flask with $20 \mathrm{ml}$ of sterile distilled water. After $24 \mathrm{hr}$ of shaking with an orbital shaker at $150 \mathrm{rpm}$ at $28 \pm 2^{\circ} \mathrm{C},\left(10^{-1}\right.$ to $10^{-8}$ ) serial dilutions of the suspension was made. Small aliquots $(50 \mu \mathrm{l})$ from dilutes of $10^{-7}$ and $10^{-8}$ were poured onto Kings B agar, nutrient agar, and Yeast extract peptone dextrose media in Petri dish for isolation of the antagonists.

The plates were incubated at $28 \pm 2{ }^{\circ} \mathrm{C}$ for 24 $48 \mathrm{hr}$ or until colony formation. Selection of single bacterial and fungal colonies was done based on morphological variation, colony characters and confirmed by different biochemical tests and after purification they were preserved in refrigerator.

\section{Isolation of fungal antagonist from rhizosphere region}

Healthy chilli plants were pulled out gently with intact roots and the excess soil adhering on roots were removed gently. Ten gram of rhizosphere soil was transferred to $250 \mathrm{ml}$ Erlenmeyer flask containing $100 \mathrm{ml}$ of sterile distilled water. After thorough shaking, the antagonist in the suspension was isolated by using serial dilution plate method (Pramer and Schmidt, 1956). From the final dilutions of $10^{-3}, 10^{-5}$ and $10^{-6}$ one $\mathrm{ml}$ of each aliquot was pipetted out, poured in sterilized Petri plate containing Trichoderma selective medium. Trichoderma spp. isolated on TSM, were purified and maintained on PDA medium. The pure cultures were maintained on respective agar slants at $4{ }^{\circ} \mathrm{C}$.

Effect of bacterial antagonists on the growth of Colletotrichum capsici under in vitro

Six isolates of Bacillus subtilis and Pseudomonas fluorescens and were tested for their antagonistic effect on growth of Colletotrichum capsici by dual culture technique (Dennis and Webster, 1971). The bacterial isolates were streaked on one side of the Petri dish $(1 \mathrm{~cm}$ away from the edge of the plate) on PDA medium and a mycelial disc ( 9 $\mathrm{mm}$ diameter) of nine days old Colletotrichum capsici culture was placed on the opposite side of the Petri dish 
perpendicular to the bacterial streak. The plates were incubated at room temperature $\left(28 \pm 2^{\circ} \mathrm{C}\right)$ for 9 days. Three replications were maintained for each isolate. After nine days of incubation, the pathogen growth and inhibition zone were measured.

Effect of fungal antagonists on the growth of Colletotrichum capsici under in vitro

Six isolates of Trichoderma spp. and Saccharomyces cerevisiae were screened against Colletotrichum capsici by dual culture method. A nine mm disc of Colletotrichum capsici and test antagonists viz., Trichoderma spp. disc was placed and Saccharomyces cerevisiae was streaked opposite to pathogen disc near the periphery of the Petri plate and incubated at room temperature $\left(28 \pm 2^{\circ} \mathrm{C}\right)$. Three replications were maintained for each isolate. The medium inoculated with the pathogen alone served as control. When the plates attained the full growth, the radial growth of the pathogen was measured in the others treatments. After nine days of incubation, mycelial growth of the pathogen and inhibition zone were measured in treated as well as control plates. Percent inhibition (PI) of mycelial growth was calculated using the formula suggested by(Pandey and Vishwakarma,1998).

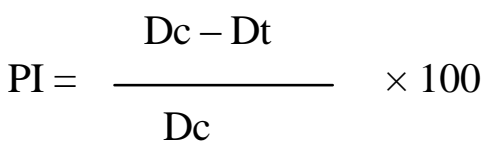

Dc $=$ Average diameter of fungal growth $(\mathrm{cm})$ in control

$\mathrm{Dt}=$ Average diameter of fungal growth $(\mathrm{cm})$ in treatment.

The growth of antagonist over the pathogen was measured nine days after incubation. The growth and zone of inhibition was measured and expressed in $\mathrm{cm}$.

\section{Results and Discussion}

Effect of Bacillus subtilis on the growth of Colletotrichum capsici under in vitro

Among the six isolates of $B$. subtilis (Bs-3) isolate was found to record maximum growth reduction of Colletotrichum capsici by 62.22 percent over control which was followed by B.subtilis (Bs- 4), which recorded the growth reduction of 55.55 per cent. The least mycelial growth reduction was recorded by B.subtilis (Bs-5) with 36.67 per cent (Table 1; Plate 1).

Effect of Pseudomonas fluorescens on the growth of Colletotrichum capsici under in vitro

Six P.fluorescens isolates were tested against the growth of Colletotrichum capsici by dual culture experiment. Among the isolates, $P$. fluorescens (Ps-1) resulted maximum growth reduction of Colletotrichum capsici by 58.88 per cent over control which was followed by $P$. fluorescens (Ps-6) which recorded the growth reduction of 55.55 per cent over control. The minimum growth reduction of 40.00 per cent was observed in $P$. fluorescens (Ps-2) (Table 2; Plate 2).

Effect of Saccharomyces cerevisiae on the growth of Colletotrichum capsici under in vitro

The effect of six isolates of Saccharomyces cerevisiae was tested against Colletotrichum capsici under in vitro conditions. Saccharomyces cerevisiae (Sc-3) was found to be effective by recording maximum mycelial growth reduction of 56.66 per cent over control which was followed by (Sc-1) which recorded the growth reduction of 54.44 per cent. The least mycelial growth reduction was recorded by (Sc-6) with 33.33 per cent (Table 3; Plate 3). 
Effect of Trichoderma spp. on the growth of Colletotrichum capsiciin vitro

The effect of six isolates of Trichoderma spp. were tested against Colletotrichum capsici under in vitro conditions. Among the antagonists tested, Trichoderma spp. (Ts-4) was found to be effective by recording maximum mycelial growth reduction of 56.66 per cent over control which was followed by Trichoderma spp. (Ts-2) which recorded the growth reduction of 52.22 per cent. The least mycelial growth reduction was recorded by Trichoderma spp. (Ts-3) with 43.33 per cent (Table 4; Plate 4).

Effect of bacterial antagonists on the growth of Colletotrichum capsici isolate under in vitro

In the present study, B. subtilis(Bs-3) isolate was found to record maximum growth reduction of Colletotrichum capsici by 62.22 percent over control which was followed by B.subtilis (Bs- 4), which recorded the growth reduction of 55.55 percent. Jeyalakshmi et al.,(1998) reported that Bacillus subtilis was used to control chilli fruit rot and die back.A novel Bacillus spp. AB1, with strong antifungal activity, was obtained from coffee phyllosphere of the Nile River in India by (Nair et al., 2002). Thirty B. subtilis isolates were evaluated under in vitro against $C$. capsici. All the isolates recorded the varied level of inhibition of mycelial growth of $C$. capsici. Among different isolates, BS16 showed maximum inhibition of 63.42 per cent followed by BS $30(57.40 \%)$ and minimum was 11.98 per cent (Rajkumar et al., 2018).

In the present investigation, P.fluorescens isolates were tested against the growth of Colletotrichum capsici by dual culture experiment. Among the isolates, P. fluorescens (Ps-6) resulted maximum growth reduction of Colletotrichum capsici by 58.88 per cent over control which was followed by $P$. fluorescens (Ps-1) which recorded the growth reduction of 55.55 per cent over control.

Similar results were reported by Birari et al., (2018) and showed that Pseudomonas flourescens have $90 \%$ of the radial growth inhibition of the pathogen Colletotrichum capsici. Linu et al., (2006) stated that the antagonistic effect of the bacterial isolates was tested against the chilli anthracnose pathogen Colletotrichum capsici by the standard dual culture method.

Table.1 Effect of Bacillus subtilis against the growth of Colletotrichum capsici under in vitro conditions

\begin{tabular}{|c|c|c|c|}
\hline S.No & Isolate code & $\begin{array}{l}\text { Radial mycelial } \\
\text { growth }(\mathbf{c m})^{*}\end{array}$ & $\begin{array}{l}\text { Per cent inhibition } \\
\text { over control }\end{array}$ \\
\hline 1 & Bs -1 & 5.00 & 44.44 \\
\hline 2 & Bs -2 & 4.40 & 52.22 \\
\hline 3 & Bs -3 & 3.80 & 62.22 \\
\hline 4 & Bs -4 & 4.00 & 55.55 \\
\hline 5 & Bs -5 & 5.70 & 36.67 \\
\hline 6 & Bs - 6 & 5.50 & 38.88 \\
\hline \multirow[t]{2}{*}{7} & Control & 9.00 & 0.00 \\
\hline & $\mathrm{CD}(\mathrm{P}=0.05)$ & 0.25 & \\
\hline
\end{tabular}

*Mean of three replications 
Table.2 Effect of Pseudomonas fluorescens against the growth of Colletotrichum capsici under in vitro conditions

\begin{tabular}{|l|c|c|c|}
\hline S.No & Isolate code & $\begin{array}{c}\text { Radial mycelial } \\
\text { growth(cm)* }\end{array}$ & $\begin{array}{c}\text { Per cent inhibition } \\
\text { over control }\end{array}$ \\
\hline $\mathbf{1}$ & Pf -1 & 3.70 & 58.88 \\
\hline $\mathbf{2}$ & $\mathrm{Pf}-2$ & 5.60 & 37.77 \\
\hline $\mathbf{3}$ & $\mathrm{Pf}-3$ & 5.00 & 44.44 \\
\hline $\mathbf{4}$ & $\mathrm{Pf}-4$ & 4.30 & 52.22 \\
\hline $\mathbf{5}$ & $\mathrm{Pf}-5$ & 4.50 & 50.00 \\
\hline $\mathbf{6}$ & $\mathrm{Pf}-6$ & 4.00 & 55.55 \\
\hline $\mathbf{7}$ & $\mathrm{Control}$ & 9.00 & 0.00 \\
\hline \multicolumn{2}{|c|}{$*$ Mean of three replications } \\
\hline
\end{tabular}

Table.3 Effect of Saccharomyces cerevisiae against the growth of Colletotrichum capsici under in vitro conditions

\begin{tabular}{|l|c|c|c|}
\hline S.No & Isolate code & $\begin{array}{c}\text { Radial mycelial } \\
\text { growth }(\mathbf{c m})^{*}\end{array}$ & $\begin{array}{c}\text { Per cent inhibition } \\
\text { over control }\end{array}$ \\
\hline $\mathbf{1}$ & $\mathrm{Sc}-1$ & 4.10 & 54.44 \\
\hline $\mathbf{2}$ & $\mathrm{Sc}-2$ & 5.00 & 44.44 \\
\hline $\mathbf{3}$ & $\mathrm{Sc}-3$ & 3.90 & 56.66 \\
\hline $\mathbf{4}$ & $\mathrm{Sc}-4$ & 5.40 & 40.00 \\
\hline $\mathbf{5}$ & $\mathrm{Sc}-5$ & 4.30 & 52.22 \\
\hline $\mathbf{6}$ & $\mathrm{Sc}-6$ & 6.00 & 33.33 \\
\hline $\mathbf{7}$ & $\mathrm{Control}$ & 9.00 & 0.00 \\
\hline & CD $(\mathbf{P}=\mathbf{0 . 0 5})$ & $\mathbf{0 . 9 5}$ & \\
\hline & *Mean of three replications \\
\hline
\end{tabular}

Table.4 Effect of Trichoderma spp. against the growth of Colletotrichum capsici under in vitro conditions

\begin{tabular}{|c|c|c|c|}
\hline S.No & Isolate code & $\begin{array}{l}\text { Radial mycelial } \\
\text { growth }(\mathbf{c m})^{*}\end{array}$ & $\begin{array}{l}\text { Per cent inhibition } \\
\text { over control }\end{array}$ \\
\hline 1 & Ts -1 & 4.90 & 45.55 \\
\hline 2 & Ts -2 & 4.30 & 52.22 \\
\hline 3 & Ts -3 & 5.10 & 43.33 \\
\hline 4 & Ts -4 & 4.10 & 54.44 \\
\hline 5 & Ts -5 & 4.80 & 46.66 \\
\hline 6 & Ts -6 & 5.00 & 44.44 \\
\hline \multirow[t]{2}{*}{7} & Control & 9.00 & - \\
\hline & $\mathrm{CD}(\mathrm{P}=0.05)$ & 0.22 & \\
\hline
\end{tabular}


Plate.1 Effect of Bacillus subtilis on the growth of Colletotrichum capsici

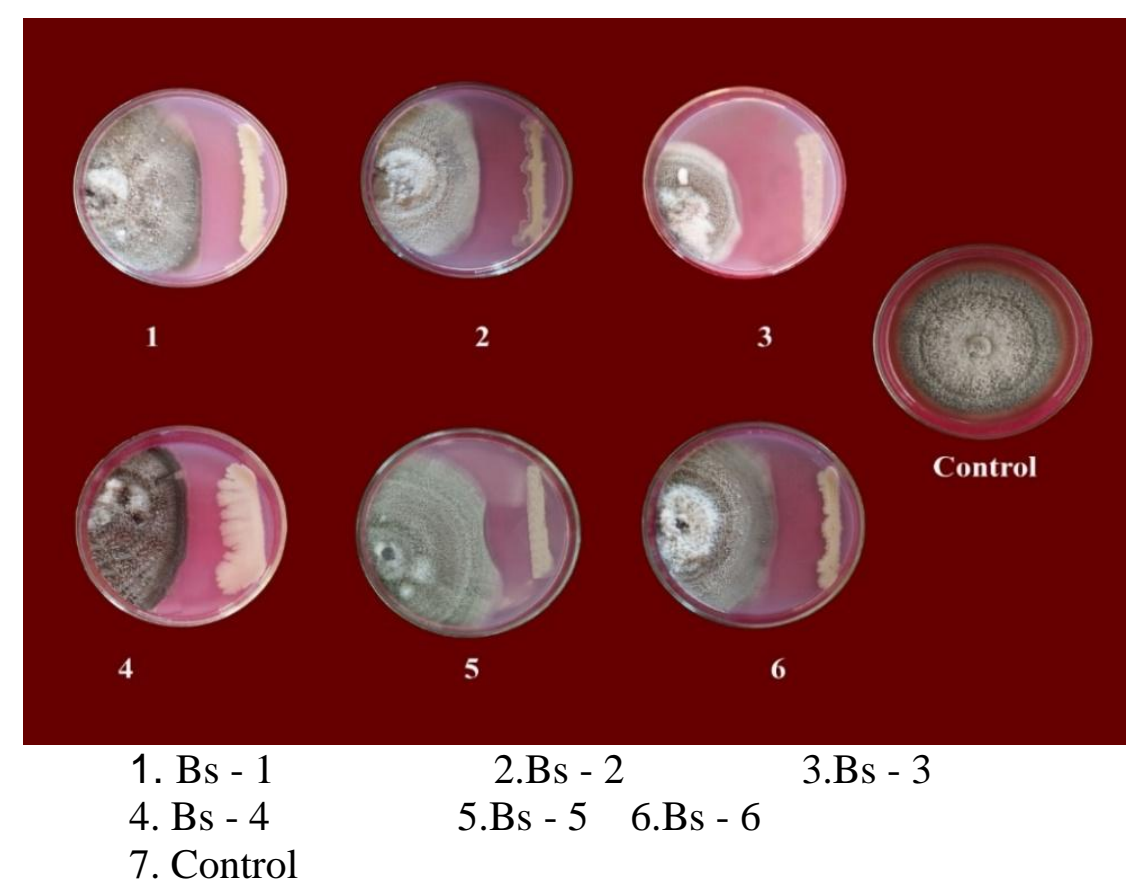

Plate.2 Effect of Pseudomonas fluorescens on the growth of Colletotrichum capsici

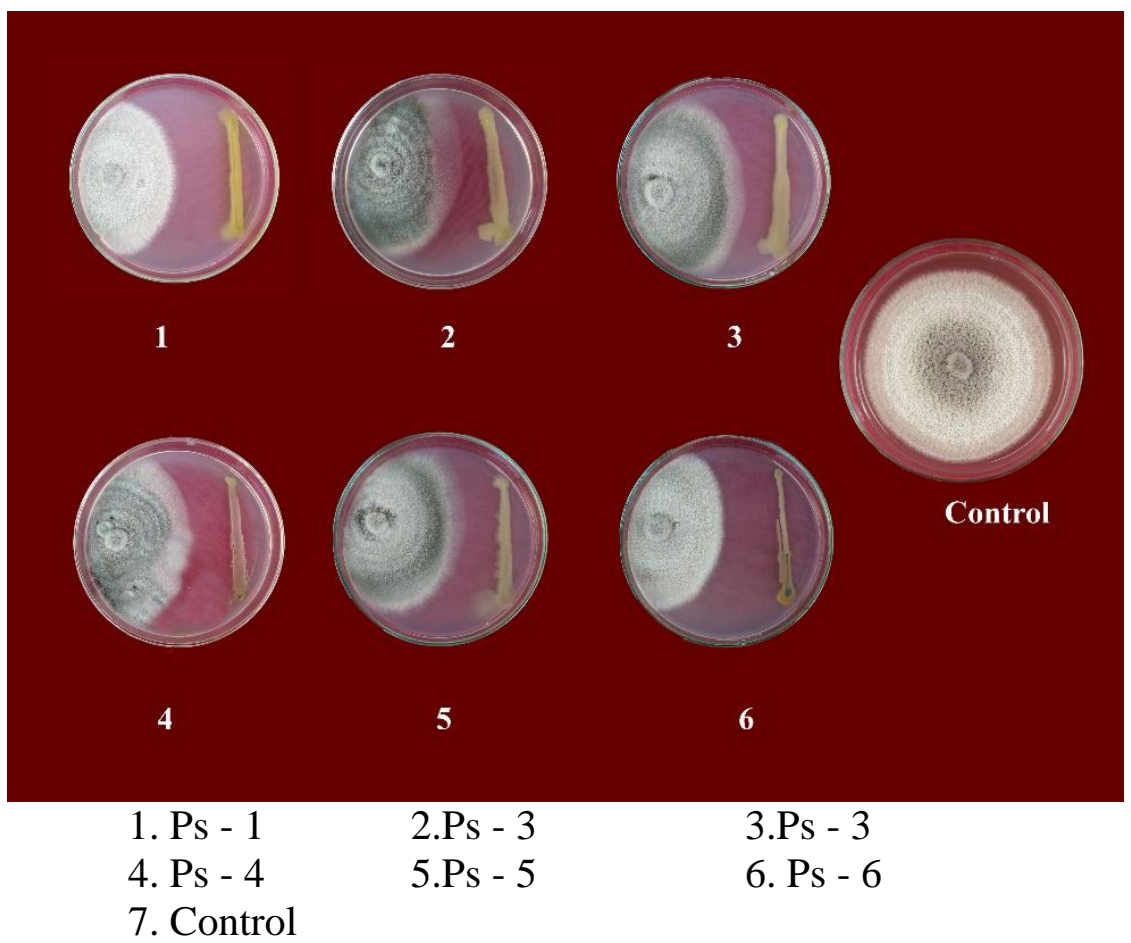


Plate.3 Effect of Saccharomyces cerevisiae on the growth of Colletotrichum capsici

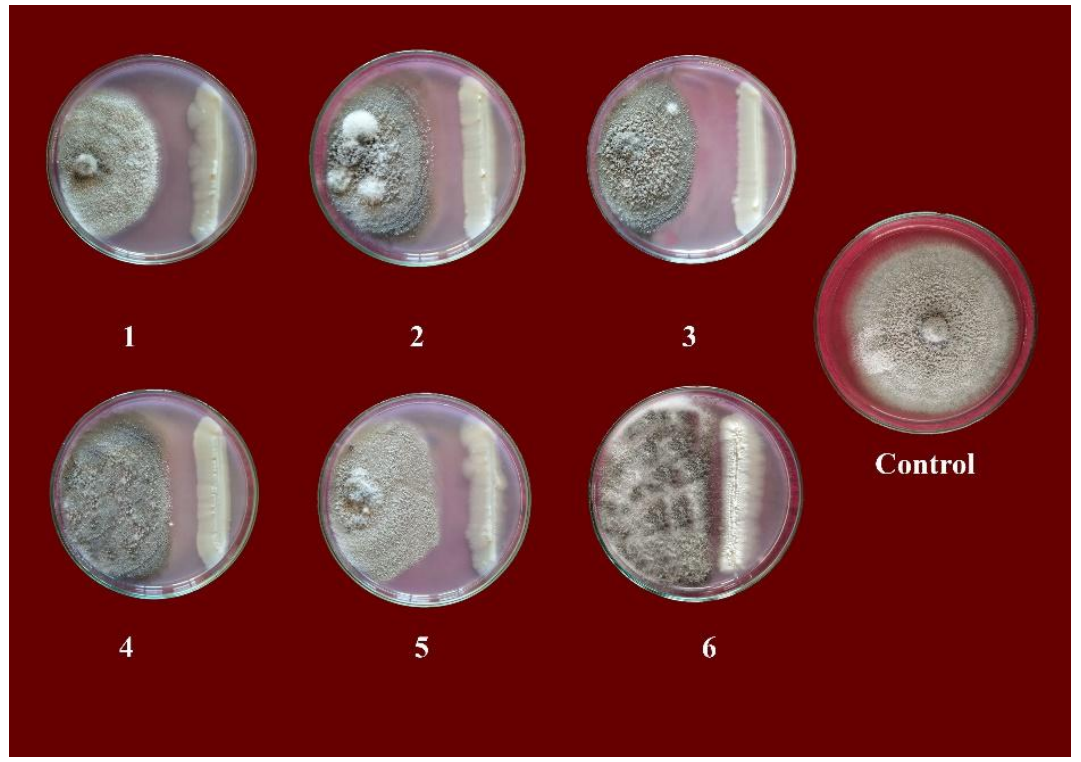
1. Sc - 1
2.Sc $-23 . \mathrm{Sc}-3$
4. Sc - 45.Sc - 5
6. $S c-6$
7.Control

Plate.4 Effect of Trichoderma spp. on the growth of Colletotrichum capsici

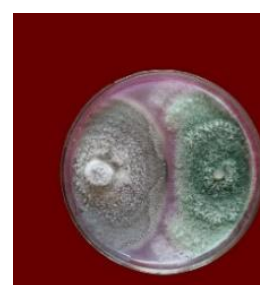

1

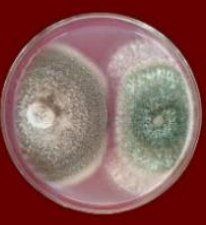

4

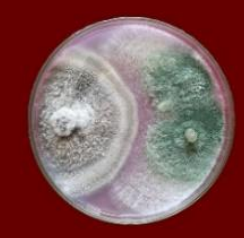

2

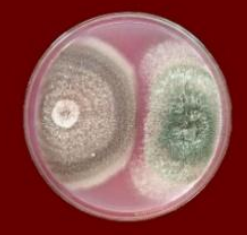

5

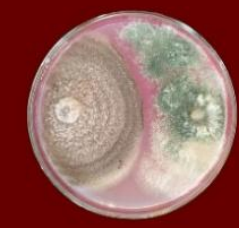

3

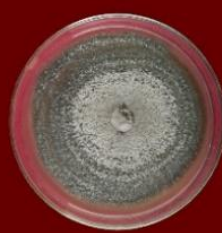

Control
1. Ts - 1
2.Ts -2
3.Ts -3
4. Ts -4
5.Ts -5
6. Ts -6
7. Control

The results revealed that among the isolates PS 2 showed maximum inhibition of $93.41 \%$ whereas the other isolate PS 3 showed $72.5 \%$ of inhibition against Colletotrichum capsici after 7 days of incubation. The biological control of three Colletotrichum 
lindemuthianum races using Pseudomonas chlororaphis PCL1391 and Pseudomonas fluorescens WCS365(Bardas et al., 2009).

The plants sprayed with only C. capsici cultures, recorded the highest disease intensity and $P$. fluorescens sprayed plant recorded least infection, this suppression of disease was attributed either to the activity of antifungal compounds produced by the microbe or the hyper parasitism on the pathogen or by ISR in the host plant which combat the pathogen infection. The rapid defense exerted by the treatment at the site of fungal entry delayed the infection process (Ramkumar et al., 2012).

Effect of Saccharomyces cerevisiae on the growth of Colletotrichum capsici under in vitro

Biological control agents such as Saccharomyces cerevisiae have been reported as antagonistic to C. capsici (Jayelakshmi and Seetharaman, 1998). The results of present experiment revealed that Saccharomyces cerevisiae (Sc-3) was found to be effective by recording maximum mycelial growth reduction of 56.66 per cent over control which was followed by (Sc-1) which recorded the growth reduction of 54.44 per cent. Lopes et al., (2015)Co-cultured C. acutatum in Petri dishes with each $S$. cerevisiae yeast isolate and observed that all yeast isolates inhibited mycelial growth of $C$. acutatum. The ACBCAT1 and ACB-CR1 isolates promoted the most inhibitions values correspond to $71 \%$ and $67 \%$, respectively. Moreover, the ACBPE2 and ACB-K1 isolates were the least effective. Three yeast isolates were isolated and showed antagonistic effect of mycelial growth of $C$. gloeosporioides and showed different Inhibition ability relative to the control treatment when cocultured with $C$. gloeosporioides. GA8 isolate exhibited highest inhibition values of $79.29 \%$.
Moreover, L24 and LFA802 isolates were less effective (Liu et al., 2018).

Effect of Trichoderma spp. on the growth of Colletotrichum capsici in vitro

In the present study, the fungal antagonist Trichoderma spp. (Ts-4) was found to be the most effective by recording maximum mycelial growth reduction of 56.66 per cent at 9 DAI. Azad et al., (2013) found that Trichoderma viride gives $77.60 \%$ growth inhibition against $C$. gloeosporioides. The inhibitory effect of volatile and non-volatile compounds released by $T$. saturnisporum, $T$. harzianum, $T$. viride and $T$. reesei against Colletotrichum capsici, a fungal pathogen responsible for anthracnose disease in bell peppers (Ajith and Lakshmidevi, 2010). Evaluated different Trichoderma strains against Colletotrichum capsici under laboratory conditions by different techniques and found the $T$. harzianum as potential antagonist for inhibition of the mycelial growth, conidial germination, germ tube elongation and disease severity of $C$. capsici (Rahman et al., 2013).

\section{References}

Ajith, P. S., and Lakshmidevi, N. (2010). Effect of volatile and non-volatile compounds from Trichoderma spp. against Colletotrichum capsici incitant of anthracnose on bell peppers. Nature and Science, 8(9), 265-269.

Azad, C. S., Srivastava, J. N., and CHAND, G. (2013). Evaluation of bio-agents for controlling fruit rot/anthracnose of banana caused by Colletotrichum gloeosporioides in-vitro condition. The Bioscan, 8(4), 12211224

Bardas, G. A., Lagopodi, A. L., Kadoglidou, K., and Tzavella-Klonari, K. (2009). Biological control of three Colletotrichum lindemuthianum races using Pseudomonas chlororaphis PCL1391 and Pseudomonas fluorescens WCS365. Biological Control, 49(2), 139-145. 
Birari, B. P., Gade, R. M., and Chuodhari, R. K. (2018). Antifungal efficacy of plant extracts, biocontrol agents against Colletotrichum capsici causing anthracnose of chilli. Journal of Pharmacognosy and Phytochemistry, 7(5), 1368-1373.

Bosland, P. W., and Votava, E. J. (2003). Peppers: vegetable and spice capsicums. $\mathrm{CAB}$ International.

Dennis, C., and Webster, J. (1971). Antagonistic properties of species-groups of Trichoderma: II. Production of volatile antibiotics. Transactions of the British Mycological Society, 57(1), 41-IN4

Jeyalakshmi, C., and Seetharaman, K. (1998). Biological control of fruit rot and dieback of chilli with plant products and antagonistic microorganism. Disease Research. 12, 46-48.

Linu, M. S., Jisha, M. S., and Jisha, M. S. (2006). In vitro control of Colletotrichum capsici induced chilli anthracnose by fungicides and biocontrol agent. Int. J. Appl. Pure Sci. Agric, 3, 27-33.

Liu, Z., Du, S., Ren, Y., and Liu, Y. (2018). Biocontrol ability of killer yeasts (Saccharomyces cerevisiae) isolated from wine against Colletotrichum gloeosporioides on grape. Journal of basic microbiology, 58(1), 60-67.

Lopes, M. R., Klein, M. N., Ferraz, L. P., da Silva, A. C., and Kupper, K. C. (2015). Saccharomyces cerevisiae: a novel and efficient biological control agent for Colletotrichum acutatum during preharvest. Microbiological research, 175, 9399.

Nair, J. R., Singh, G., and Sekar, V. (2002). Isolation and characterization of a novel
Bacillus strain from coffee phyllosphere showing antifungal activity. Journal of applied microbiology, 93(5), 772-780.

Pandey, K. K., and Vishwakarma, S. N. (1998). Growth, sporulation and colony characters of Alternaria alternata on different vegetable-based media. Journal of Mycology and Plant Pathology (India).

Pramer, D., and Schmidt, E. L. (1956). Exp. Soil Micro.

Rahman, M. A., Razvy, M. A., and Alam, M. F. (2013). Antagonistic activities of Trichoderma strains against chili anthracnose pathogen. Int. J. Microbiol. Mycol, 1(1), 7-22.

Rajkumar, K., Naik, M.K., Amaresh, Y.S., and Chennappa, G. (2018). Bioefficacy of Bacillus subtilis against Major Pathogen of Chilli Colletotrichum capsici Causing Fruit Rot of Chilli. Int.J.Curr.Microbiol.App.Sci., 7(7): 2681-2686

Ramkumar, R., Soureche, S., Prabhakar and Muthuraman Pandurangan. (2012). Role of antagonistic microbe Pseudomonas fluorescens on Colletotrichum capsici infecting Curcuma longa. Plant PatholMicrob. 3:7

Rangswamy, G., and Mahadevan, A. (1999). Diseases of Crop Plants in India Prentice Hall India Pvt. Ltd., New Delhi.

Roberts, P. D. (2001). Anthracnose caused by Colletotrichum sp. on pepper. University of Florida Cooperative Extension Service, Institute of Food and Agricultural Sciences, EDIS.

Singh, S., Prajapati, R. K., and Srivastava, S. S. L. (2005). Efficacy of fungicides against Sclerotium rolfsii causing collar rot in lentil. Farm Sci J, 14(2), 68-69.

\section{How to cite this article:}

Kavi Bharathi, N., N. Revathy, E.G. Ebenezar and Gnanamalar, R.P. 2019. In vitro Antagonistic Activity of Fungal and Bacterialbio Control Agents against Chilli Fruit Rot Incited by Colletotrichum capsici. Int.J.Curr.Microbiol.App.Sci. 8(05): 190-198. doi: https://doi.org/10.20546/ijcmas.2019.805.023 